Songs and Poetry

Canadian Journal of Family and Youth, 9(1), 2017, pp 27-32

ISSN 1718-9748 (C) University of Alberta

http://ejournals.library.ualberta.ca/index/php/cjfy

\title{
A Compilation of Four Family-Oriented Songs
}

\author{
Theresa "Muskeg Mama” Poirier
}

\begin{abstract}
Author's Note
The first song was written in one morning for the CBC hockey contest on October 5, 2013. The song is about hockey but it turned into a song about my dad's role in our family life in western Canada circa 1960's. The next two songs I can attribute directly to the legacy and fallout of residential schools and the foster care system in Alberta on my family life. The fourth song was sparked by my daughter's make-up business and home life with children.
\end{abstract}




\section{I'm a Hockey Lover}

My dad he was a sportsman, he played all kinds of ball

But hockey was his favorite game and he rose to meet that call!

First a fan, then a player ... then a fan again

My dad he was a hockey lover and he was loyal to the end!

He taught us how to play the game and on those days we lost

He taught us how to hold our heads high, despite of the cost!

He taught us how to keep it clean, we tried to play it straight

Cause on hockey nights... we got to stay up late!

First a fan, then a player ... then a fan again

I'm a hockey lover and I'm loyal to the end!

First a fan, then a player ... then a fan again

I'm a hockey lover and I'm loyal to the end!

Now that I'm a parent, I've got babies of my own

I'm grateful for those many hours playin' outside in the cold!

Hockey's kept me healthy, makes me happy, keeps me sharp

Hockey blood runs through my veins, directly to my heart!

First a fan, then a player ... then a fan again

I'm a hockey lover and I'm loyal to the end!

First a fan, then a player ... then a fan again

I'm a hockey lover and I'm loyal to the end!

Across the many nations and for many a good year

Hockey fans from far and wide all rise to give a cheer!

So when Lord Stanley comes to call, forgive when I send...

A tidy note with my regrets... cause' I'm a hockey fan my friend!

First a fan, then a player ... then a fan again

I'm a hockey lover and I'm loyal to the end!

First a fan, then a player ... then a fan again

I'm a hockey lover and I'm loyal to the end!

I'm a hockey lover and I'm loyal to the end! 
Four Family-Oriented Songs

\section{Am a Warrior}

I started off my morning when I was wee,

I went into the Sun but they were waiting there for me!

First they took my love; they tried to take my heart,

Then they stole my dreams... as they ripped my world apart!

I thought they were my friends, thought they were my family,

But some of them were evil, they were waiting there for me!

Yeah, some of them were evil; they were waiting there for me!

They tried to break my spirit ... they tried to steal my soul...

They tried to use my body and leave me in a hole!

Later in the afternoon I tried to take a nap,

I tried to sleep my pain away, leave it in the past!

I thought they were my friends, thought they were my family,

But some but some of them were evil, they were waiting there for me!

Yeah, some of them were evil; they were waiting there for me!

No matter how hard I try, I never get to rest, there`s always hurt in my head,

This life has been a test!

But now in the evening light, the truth begins to dawn...

That I am a Warrior ... and the fight for love goes on!

Yeah, I am a Warrior ... and the fight for love goes on!

\section{Hurtin' Girl}

I used to have two sisters... one of them is dead,

Evil tried to take them... attack them in their bed,

Me I $m$ half mad, loose and on the run...

Yeah I'm a hurtin 'girl ... oh yeah I'm a hurtin 'girl!

I used to have two brothers but they're already dead,

I have a third that they say...is out of this head,

Me I $m$ half mad, for the life I've led...

Yeah I'm a hurtin 'girl ... oh yeah I’m a hurtin 'girl!

I used to have two husbands ... lost my one true love,

I'm sick and tired of the one I'm with, think I ve had enough,

Me Im half mad, this I know for sure...

Yeah I'm a hurtin 'girl ... oh yeah I'm a hurtin 'girl!

I used to work long and hard... not too much to show, I put all of my faith into men ... what little did I know,

Me I $m$ half mad, Ill soon be on the road...

Yeah I'm a hurtin `girl... oh yeah I'm a hurtin 'girl! 


\section{Girlie}

Girlie gets up early when the Sun hits her lashes

She gets up slow, glides across the floor

Girlie finds her make-up, dresses up her lashes

She finds her coat n' shoes, she's glidin' out the door

The kids are cryin', while the Sun is shinin', the kids are cryin' again

The kids are cryin', the Sun is shinin'... she could use a friend

Girlie gets a lover, she builds a family

She gets up early; puts the kettle on

Girlie finds her make-up, dresses up her family

She finds their coats and shoes, she helps them put them on

The kids are cryin', the Sun is shinin', the kids are cryin' D again

The kids are cryin', while the Sun is shinin'... she could use a friend

Girlie getting' wiser with every moment

She gets up early before the dawn

Girlie finds her make-up, dresses up her family

She finds their coats and shoes; she finds her love is gone

The kids are cryin', the Sun is shinin', the kids are cryin' again

The kids are cryin', while the Sun is shinin'... she could use a friend

Girlie gets up early when the Sun hits her lashes

She gets up slow, glides across the floor

Girlie finds her make-up, dresses up her lashes

She finds her coat n' shoes, she's glidin' like before

The kids are cryin', the Sun is shinin', the kids are cryin' again

The kids are cryin', while the Sun is shinin'... she could use a friend 
Four Family-Oriented Songs

\section{Author's Biography}

I decided that there was no fun in my life. I had to change that. Then one day, I came across a \$20.00 ukulele while Christmas (2012) shopping. I plucked and strummed, and by the fall of 1999, I had a great desire to get a guitar. I bought one even though I had never really had much experience with playing one before. One ex had shown me a few chords in the seventies. I learned one song but nothing substantial. But Uke (my ukulele's name) invigorated and empowered me. On February 14, 2013, I picked up the guitar and played a song by ear. I went online, learnt a song a week for twelve weeks, and then got a busker's permit for the LRT (light rail transit) in Edmonton, Alberta. Three months later on July 29. 2013, I wrote my first song, "If I Was a Doggie" aka "Chase that Cat."

The song was inspired by Sparky, my cat ...he behaved like a dog and loved my playing. He was also the inspiration for my fifth song, "When My Mama Plays". I call on experiences, visions, dreams, nightmares, fears, desires, imagination and then some, to create songs. I also try writing from other people's perspectives. The genres that I write in are as varied as my experiences. To date, I have written over 125 songs. They are blues, country, rock-a-billy, gospel, folk, rock and alternative genres.

Aside, but in association to music, I painted pictures during my cancer treatment and recovery. Later, I painted pictures to decorate my guitar case. People began buying my pictures. I did a few paintings and artisan projects (included in a portfolio) through which I was commissioned by the Aboriginal Education Center in MacEwan University city center campus to create a piece for their reception area which was completed in January 2016.

I draw inspiration from life, from being a mother, a lover, a grandmother, an ex, a sister, a daughter. I siphon culture. I've lived across Canada and on armed forces bases. I am half Metis 
Poirier

and half Irish. Recovering from cancer, testifying at the TRC (Truth and Reconciliation Commission in Canada) in 2014, surviving various abusive relationships (spousal, child and sexual), dealing with Graves' disease (hyperthyroidism), ageism, poverty, racism, sexism, dealing with trauma, violence and rape and even graduation from MacEwan University are fodder for music, lyrics and stories. Human nature, the natural environment, and the political and economic state of affairs are also fair game for creativity.

My reasons for writing songs are diverse. I may want to clear my conscience (narrative therapy), teach a lesson, have fun and entertain, make a social statement, earn a living or all of the above. I picked the name "Muskeg Mama" for a number of reasons but mostly because it suits me and my style.

Along with my musical calling, I am looking into a career in music therapy. However writing stories, producing art, music and even theater are foreseeable. I have currently written a number of children's songs which are educational and entertaining. I enjoy playing for everybody but children are especially fun and I like day work! 